ScIDice

\section{Effect of Different Simulated Microwave Disinfection Cycles on Hardness, Roughness and Gloss of Acrylic Resins}

\section{International Journal of Dentistry and Oral Science (IJDOS) ISSN: 2377-8075}

Capla $\mathrm{M}^{1}$, Sardi $\mathrm{JC}^{2}$, Pfeifer $\mathrm{C}^{3}$, Consani RLX ${ }^{4 *}$

${ }^{1}$ PhD, Department of Prosthodontics and Periodontology, Piracicaba Dental School, State University of Campinas, Piracicaba, SP, Brazil.

${ }^{2} \mathrm{PhD}$, Department of Physiological Sciences, Piracicaba Dental School, State University of Campinas, Piracicaba, SP, Brazil.

${ }^{3}$ Professor, Department of Restorative Dentistry, Division of Biomaterials and Biomechanics, Oregon Health and Science University, Portland, OR, USA.

${ }^{4}$ Professor, Department of Prosthodontics and Periodontology, Piracicaba Dental School, State University of Campinas, Piracicaba, SP, Brazil.

\title{
Abstract
}

Objectives: This study evaluated the effect of microwave disinfection on hardness, roughness and gloss of acrylic resins for denture base.

Materials and Methods: Samples (20 $\mathrm{mm}$ in diameter and $2 \mathrm{~mm}$ in height) were prepared using QC-20, Onda Cryl, Classico, Vipi Cril Plus, Vipi Wave, and Vipi Characterized acrylic resins according to manufacturers' recommendations. After polymerization procedures, the samples were bench cooled, deflasked and conventionally finished and polished. The samples were immersed in glass vessel containing $150 \mathrm{~mL}$ of water and subjected to disinfection cycles at 7, 14, 21 and 30 days. Four disinfections of $650 \mathrm{~W} / 1 \mathrm{~min}$ was performed in each cycle using microwave oven. The samples were water stored at $37^{\circ} \mathrm{C}$ between each cycle. Average of three readings for each sample was considered as values of roughness (Ra, $\mu$ m), Knoop hardness number $(50 \mathrm{kgf} / 10 \mathrm{~s})$, and gloss (GU - 60 degrees). The samples were analyzed at baseline, and after disinfection cycles. Data were submitted to two-way ANOVA for repeated measures considering the factors disinfection and acrylic resin, and followed by Tukey's test $(5 \%)$.

Results: Roughness ranged from 0.295 to $0.842 \mu \mathrm{m}$, Knoop hardness from 20.69 to $25.24 \mathrm{KHN}$, and gloss from 65.52 to 82.74 GU.

Conclusions: Roughness, Knoop hardness and gloss values of different acrylic resins for denture base were differentelly influenced after subjected to disinfection cycles at 7, 14, 21 and 30 days.

Clinical Relevance: Factors as hardness, roughness, and gloss are essential to avoid the formation of biofilm in prostheses; therefore, the smoother is the denture base, the easier is the cleaning and comfort for the patients, whatever the disinfection method used.

Keywords: Acrylic Resin; Microwave Disinfection; Hardness; Roughness; Gloss.

\section{Introduction}

Denture bases are commonly made with acrylic resin based on poly-methyl metacrylate. One of the relevant conditions for the use of this type of prosthesis concern the cleaning that should avoid that the denture causes any oral health problem for the patients. Denture may produce alterations in the oral microbiota by facilitating the accumulation of fungus and bacteria, which can be associated to several oral pathological processes [1].
Denture base needs to be polished because a smooth surface is more comfortable to the patients, and favors the cleaning by the tooth brushing. Deficient denture cleaning and poor oral cavity hygiene, carbohydrate-rich diet, xerostomia and local trauma of soft tissues were considered as predisposing factors for installation of the prosthetic stomatitis [2]. The treatments indicated for the prosthetic stomatitis include the use of antiseptics or antifungal drugs and effective regimen of oral hygiene to prevent or

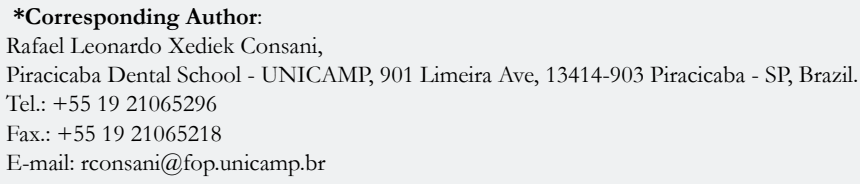

Copyright: Consani $\mathbf{R L X}{ }^{\circ}$ 2017. This is an open-access article distributed under the terms of the Creative Commons Attribution License, which permits unrestricted use, distribution and reproduction in any medium, provided the original author and source are credited. 
control the formation of the biofilm on the prostheses [3].

The methods commonly used to clean dentures and remove the biofilm are tooth brushing with abrasive dentifrice, chemical cleanser, and the association between tooth brushing and chemical cleanser [4-7]. However, a previous study demonstrated that microwave radiation was effective in the inactivation of microorganisms of complete dentures [8].

Hardness and surface roughness are factors related to characteristics of the acrylic resin surface and considered essential for maintenance and durability of the prostheses. Hardness is a mechanical property related to resistance of the denture in the oral environment, while roughness is associated to the surface smoothness level of acrylic resin bases. Thus, the smoother is the denture base, the easier is the cleaning and comfort for the patients, whatever the conventional lathe polishing techniques [9].

Classic studies showed that smaller values of surface roughness hinder the formation of bacterial biofilm. The prolonged use of domestic products or abrasive toothpastes for total prosthesis hygienization is unsuitable for the acrylic resin surface [10]. Besides, other factors may also affect the denture surface characteristics, depending on the polishing type [11], and disinfection methods [12], since they should provide a clean surface avoiding the formation of biofilm. In addition, the gloss of acrylic resins for dental prosthesis may be influenced by different types of cleansers [13].

Denture irradiation by microwave energy is an alternative to the traditional disinfection methods to prevent or treat the prosthetic stomatitis [14]. Studies demonstrated that the disinfection using $650 \mathrm{~W}$ for $6 \mathrm{~min}$ was effective in the sterilization of acrylic resins colonized by Candida albicans $[8,15]$. Although the microwave radiation had been efficient in the sterilization process, possible harms on the mechanical and viscoelastic properties of the acrylic resin still need to be best clarified. Previous studies have shown that the disinfection by microwave energy decreased the hardness of some acrylic resin types, but no effect was observed on the impact and flexural strength [16]. Repeated microwave disinfections decreased the Knoop hardness and showed no effect on the impact strength, while the flexural strength was similar for all evaluated acrylic resins [17]; however,though the roughness after brushing was not significantly affected by microwave disinfection, a increased microwave cycles resulted in greater roughness [18].

Moreover, some authors have also investigated the effects of the microwave disinfection on the dimensional stability and adaptation of complete denture bases. Treatment in microwave oven at $604 \mathrm{~W}$ for $10 \mathrm{~min}$ produced the greatest discrepancies in the adaptation of maxillary acrylic resin denture bases to the stone casts [19]. Disinfection by microwave energy improved denture base adaptation when the traditional flask closure method was used, but did not alter the base adaptation in the restrictive flask closure method [20]. Moreover, surface roughness increased in the mechanical polishing with microwave disinfection and decreased with the chemical polishing [21].

Based on these considerations, it would be opportune to evaluate the effect of microwave disinfection cycles on surface roughness, Knoop hardness and gloss of acrylic resins for denture bases. The hypothesis studied was that roughness, hardness and gloss of acrylic resins would be similarly affected by the different cycles of microwave disinfection.

\section{Materials and Methods}

\section{Samples Preparation}

Wax matrices (Lysanda Dental Products, Sao Paulo, SP, Brazil) obtained in laboratorial silicone molds $(20 \mathrm{~mm}$ diameter and 2 $\mathrm{mm}$ height) were traditionally included in metallic (Safrany; Safrany Metallurgy, Sao Paulo, SP, Brazil) or plastic (Vipi STG, Vipi Articles Dental, Pirassununga, SP, Brazil) flasks with type III dental stone (Herodent; Vigodent, Rio de Janeiro, RJ, Brazil). After wax matrices inclusion for 1 hat room temperature, the flasks were open, the wax matrices removed, the stone molds cleaned with household detergent (Ypê, Amparo, SP, Brazil) for removal of wax traces and petroleum jelly used as stone dental insulating. Twenty samples were made in the stone molds for each acrylic resin ( $\mathrm{n}=20)$ : Vipi Cril Plus conventional, Vipi Wave microwaved, and Vipi Characterized conventional (Vipi Dental Products, Pirassununga, SP, Brazil), Classico conventional and Onda Cryl microwaved (Classico Dental Products, Sao Paulo, SP, Brazil), and QC-20 conventional (Dentsply; Petropolis, RJ, Brazil). According to manufacturers, the acrylic resins present basic composition containing poly-methyl methacrylate (polymer), methyl methacrylate (monomer), hydroquinone as inhibitor, benzoyl peroxide (initiator), cross-linker agent, and pink pigment.

Polymer/monomer ratio for each acrylic resin type was according to manufacturers' recommendations, and the resulting acrylic resin mass conventionally pressed in the dough-like stage in metallic (Vipi Cryl Plus, Vipi Characterized, Classico and QC-20) or plastic (Vipi Wave and Onda Cryl) flasks. The thermopolymerized acylic resins were cured in metallic flask by the methods (1) heated water bath at $74^{\circ} \mathrm{C}$ for $9 \mathrm{~h}$ or (2) microwaved in plastic flasks at $1,400 \mathrm{~W}$ in microwave oven $(10 \%$ potency at $20 \mathrm{~min}+40 \%$ by $5 \mathrm{~min}$ for the Vipi Wave, and $30 \%$ potency for $4 \mathrm{~min}+50 \%$ by $3 \mathrm{~min}$ for Onda Cryl). After polymerization, the samples were deflasked after flask cooling at room temperature, conventionally finished and polished in lathe by method commonly used in prosthetic laboratories, and stored in stove at $37^{\circ} \mathrm{C}$ for $24 \mathrm{~h}$ immersed in water until the disinfection procedure of the samples.

\section{Samples Disinfection}

Samples were immersed in glass vessel containing $150 \mathrm{~mL}$ of water and subjected to disinfection cycles at 7, 14, 21 and 30 days. Four repeated disinfections of $650 \mathrm{~W} / 1 \mathrm{~min}$ were made in each cycle performed in domestic microwave oven (Continental; Manaus, AM, Brazil). Between each cycle, the samples were water stored at $37^{\circ} \mathrm{C}$ in stove.

\section{Roughness Testing}

The measures of surface roughness were carried out with rugosimeter (Surfcorder SE1700; Kosaka, Tokyo, Japan) with a diamond tip with radius of $0.5 \mu \mathrm{m}$ and accuracy of $0.01 \mu \mathrm{m}$ using the ANSI standard (cut-off of $0.250 \mathrm{~mm}$, length of $1,250 \mathrm{~mm}$ and speed of $0.100 \mathrm{~mm} / \mathrm{s})$. Three measurements were performed on the surface of each sample. The arithmetc average was considered as roughness value $(\mathrm{Ra}, \mu \mathrm{m})$ for each sample. The roughness avaliation was carried out in the periods of baseline and after dis- 
infection cycles at $7,14,21$, and 30 days.

\section{Knoop Hardness Testing}

Each sample was subjected to three Knoop indentations (Shimadzu, model HMV-2; Tokyo, Japan) with load of $50 \mathrm{gf}$ for $10 \mathrm{~s}$. The arithmetc average was considered as Knoop hardness value for each sample. The hardness avaluation was carried out in the periods of baseline and after disinfection cycles at 7, 14, 21, and 30 days, in different regions previously demarcated in the sample surface.

\section{Gloss Testing}

The gloss value was measured with glossmeter (ZGM 1120 Glossmeter - Zehntner GmbH Testing Instruments; Switzerland). The glossmeter measured the intensity of the reflected light and compared with the reference value obtained with a black glass supplied by the manufacturer. Each sample was subjected to three measurements with incidente light of 60 degrees. The arithmetc average was considered as the gloss unit value (Gloss Unit GU), and recorded in a software.The gloss evaluation was carried out at baseline and after disinfection cycles at 7, 14, 21, and 30 days.

\section{Statistical Analysis}

Obtained data were submitted to two-way ANOVA for repeated measures and Tukey's test with significance level of $\alpha=0.05$. It was used the SigmaPlot 12 (Systat Software Inc. San Jose, California, USA) statistical program. Previously to statistical analysis, the roughness and hardness values were transformed in square root to enable a normality test. The factors considered were acrylic resin and disinfection.

\section{Results}

\section{Roughness}

Roughness means for acrylic resins submitted to microwave disinfection are shown in Table 1. At baseline (no disinfection), Classico showed highest value followed by QC-20, Onda Cryl and Vipi Characterized. Vipi Cril Plus presented lowest value while Vipe Wave was intermediate. After disinfection cycle at 7 days, Classico showed highest value followed by Onda Cryl and Vipi Cril Plus. Vipi Wave showed lowest values while QC-20 and Vipi Characterized were intermediaries. After disinfection cycle at 14 days, Classico showed highest value followed by Onda Cryl and Vipi Wave.
QC-20, Vipi Cril Plus and Vipi Characterized presented lowest values while Onda Cryl was intermediate. After disinfection cycle at 21 days, Classico showed highest value followed by Onda Cryl. Vipi Cril Plus presented lowest value while QC-20, Vipi Wave and Vipi Charcterized were intermediaries. After disinfection cycle at 30 days of disinfection, Classico showed highest value followed by Vipi Wave while QC-20, Onda Cryl, Vipi Cril Plus and Vipi Characterized showed lowest values. Comparing cyclesin relation to each resin, roughness values were similar among cycles for QC- 20, Onda Cryl and Vipi Characterized. For Classico, highest roughness was at 30 days followed by baseline, and at 7 and 21 days with similar values while at 14 days was intermediate. For Vipi Cril Plus, highest roughness was at 30 days followed by 21 days, and lowest at baseline and at 7 days while at 14 days was intermediate. Vipi Wave showed highest value at 30 days followed by 14 days, and lowest for baseline and at 7 days while at 21 days was intermediate.

\section{Knoop Hardness}

Hardness means for acrylic resins submitted to microwave disinfection are shown in Table 2. At baseline (no disinfection), Onda Cryl presented highest hardness followed by Vipi Cril Plus and Vipi Wave while QC-20, Classico and Vipi Characterized were intermediaries. After disinfection cycle at 7 days, Onda Cryl showed highest value followed by QC-20, Classico and Vipi Wave while Vipi Cril Plus and Vipi Characterized were intermediaries. After disinfection cycles at 14 and 21 days, there was not difference among hardness for all resins. After disinfection cycle at 30 days, Onda Cryl showed highest value followed by Vipi Wave while QC-20, Classico, Vipi Cril Plus, and Vipi Characterized were intermediaries.

Comparing cycles in relation to each resin, hardness values for all cycles were similar only for Vipi Cril Plus. For QC-20, baseline showed highest value followed by cycleat 30 days. Lower values were shown for cycles at 14 and 21 days while cycleat 7 days was intermediate. For Onda Cryl, baseline showed highest value followed by cycles at 7 and 30 days, and cycles at 14 and 21 days showed lowest values. For Classico, baseline showed highest value followed by cycle at 30 days, and cycle at 21 days showed lowest value while cycles at 7 and 21 days were intermediaries. For Vipi Wave, baseline showed highest value followed by cycles at 7 , 14 and 21 days while cycle at 30 days was intermediate. For Vipi Characterized, baseline showed highest value followed by cycle at 30 days, and cycles at 14 and 21 days showed lowest values while cycle at 7 days was intermediate.

Table 1. Mean roughness values $(\mathrm{Ra}-\mu \mathrm{m})$ and standard deviation for acrylic resins at baseline and after disinfection cycles at 7, 14, 21 and 30 days.

\begin{tabular}{|c|c|c|c|c|c|c|}
\hline \multirow{2}{*}{ Cycle } & \multicolumn{6}{|c|}{ Surface roughness $(\mathrm{Ra}-\mu \mathrm{m})$} \\
\hline & $Q C-20$ & Onda Cryl & Classico & Vipi Cril Plus & Vipi Wave & Vipi Characterized \\
\hline Baseline & $0.426(0.009) \mathrm{Ba}$ & $0.510(0.051) \mathrm{Ba}$ & $0.735(0.057) \mathrm{Ab}$ & $0.295(0.059) \mathrm{Cc}$ & $0.353(0.123) \mathrm{BCc}$ & $0.415(0.031) \mathrm{Ba}$ \\
\hline 7 & $0.419(0.037) \mathrm{BCa}$ & $0.505(0.065) \mathrm{Ba}$ & $0.707(0.052) \mathrm{Ab}$ & $0.303(0.053) \mathrm{Cc}$ & $0.319(0.106) \mathrm{Cc}$ & $0.422(0.017) \mathrm{BCa}$ \\
\hline 14 & $0.439(0.044) \mathrm{Ca}$ & $0.491(0.112) \mathrm{BCa}$ & $0.756(0.038) \mathrm{Aab}$ & $0.365(0.062) \mathrm{Cbc}$ & $0.573(0.113) \mathrm{Bb}$ & $0.401(0.065) \mathrm{Ca}$ \\
\hline 21 & $0.469(0.117) \mathrm{BCa}$ & $0.530(0.016) \mathrm{Ba}$ & $0.720(0.087) \mathrm{Ab}$ & $0.386(0.106) \mathrm{Cb}$ & $0.662(0.156) \mathrm{ABab}$ & $0.440(0.094) \mathrm{BCa}$ \\
\hline 30 & $0.420(0.049) \mathrm{Ca}$ & $0.448(0.109) \mathrm{Ca}$ & $0.842(0.048) \mathrm{Aa}$ & $0.496(0.094) \mathrm{Ca}$ & $0.720(0.134) \mathrm{Ba}$ & $0.464(0.107) \mathrm{Ca}$ \\
\hline
\end{tabular}

Means followed by different capital letters in each row and by lowercase letters in each column differ by Tukey's test (5\%). 
Table 2. Mean hardness values (Knoop) and standard deviation for acrylic resins at baseline and after disinfection cycles at $7,14,21$ and 30 days.

\begin{tabular}{|c|c|c|c|c|c|c|}
\hline \multirow{2}{*}{ Cycle } & \multicolumn{7}{|c|}{ Knoop hardness } \\
\cline { 2 - 7 } & $\boldsymbol{Q C}-2 \boldsymbol{O}$ & Onda Cryl & Classico & Vipi Cril Plus & Vipi Wave & Vipi Characterized \\
\hline Baseline & $23.39(1.20) \mathrm{ABa}$ & $25.24(1.32) \mathrm{Aa}$ & $23.80(1.67) \mathrm{ABa}$ & $22.74(1.01) \mathrm{Ba}$ & $22.50(0.55) \mathrm{Ba}$ & $24.03(0.95) \mathrm{ABa}$ \\
\hline 7 & $21.38(0.67) \mathrm{Bbc}$ & $23.08(0.95) \mathrm{Ab}$ & $21.79(1.10) \mathrm{Bbc}$ & $22.46(0.66) \mathrm{ABa}$ & $21.20(1.52) \mathrm{Bb}$ & $22.42(0.76) \mathrm{ABbc}$ \\
\hline 14 & $20.69(0.59) \mathrm{Ac}$ & $21.28(1.40) \mathrm{Ac}$ & $21.86(0.96) \mathrm{Abc}$ & $21.68(0.90) \mathrm{Aa}$ & $20.69(1.61) \mathrm{Ab}$ & $21.61(1.05) \mathrm{Ac}$ \\
\hline 21 & $20.92(0.62) \mathrm{Ac}$ & $21.25(1.51) \mathrm{Ac}$ & $21.74(1.26) \mathrm{Ac}$ & $21.97(0.70) \mathrm{Aa}$ & $21.05(0.96) \mathrm{Ab}$ & $21.21(0.39) \mathrm{Ac}$ \\
\hline 30 & $22.08(0.64) \mathrm{ABb}$ & $23.35(0.87) \mathrm{Ab}$ & $22.87(0.47) \mathrm{ABb}$ & $22.72(0.51) \mathrm{ABa}$ & $21.93(0.95) \mathrm{Bab}$ & $22.79(0.69) \mathrm{ABb}$ \\
\hline
\end{tabular}

Means followed by different capital letters in each row and by lowercase letters in each column differ by Tukey's test (5\%).

Table 3. Mean gloss values (GU) and standard deviation for acrylic resins at baseline and after disinfection cycles at 7, 14, 21 and 30 days.

\begin{tabular}{|c|c|c|c|c|c|c|}
\hline \multirow{2}{*}{ Cycle } & \multicolumn{7}{|c|}{ GlossParte inferior do formulário(GU) } \\
\cline { 2 - 7 } & $\boldsymbol{Q C}-20$ & Onda Cryl & Classico & Vipi Cril Plus & Vipi Wave & Vipi Characterized \\
\hline Baseline & $82.74(1.87) \mathrm{Aa}$ & $81.54(3.05) \mathrm{Aa}$ & $65.99(11.03) \mathrm{Ba}$ & $78.41(5.80) \mathrm{Aa}$ & $74.40(6.58) \mathrm{Ba}$ & $76.67(9.47) \mathrm{ABa}$ \\
\hline 7 & $80.95(2.63) \mathrm{Aa}$ & $77.32(4.95) \mathrm{Ab}$ & $66.40(9.20) \mathrm{Ba}$ & $75.68(3.93) \mathrm{Aab}$ & $71.77(5.46) \mathrm{Bab}$ & $72.57(11.32) \mathrm{ABb}$ \\
\hline 14 & $78.89(3.13) \mathrm{Aa}$ & $74.37(5.59) \mathrm{ABbc}$ & $65.52(6.44) \mathrm{Ba}$ & $72.53(4.85) \mathrm{ABb}$ & $68.83(6.10) \mathrm{Bb}$ & $72.16(8.54) \mathrm{ABbc}$ \\
\hline 21 & $77.21(2.80) \mathrm{Ab}$ & $70.93(5.47) \mathrm{ABc}$ & $65.81(8.00) \mathrm{Ba}$ & $69.05(4.56) \mathrm{ABbc}$ & $66.53(6.19) \mathrm{Bbc}$ & $68.47(10.22) \mathrm{Bc}$ \\
\hline 30 & $74.11(4.02) \mathrm{Ab}$ & $68.93(5.34) \mathrm{ABc}$ & $65.96(6.45) \mathrm{ABa}$ & $66.26(4.68) \mathrm{ABc}$ & $64.92(6.01) \mathrm{Bc}$ & $67.60(8.71) \mathrm{ABc}$ \\
\hline
\end{tabular}

Means followed by different capital letters in each row and lowercase letters in each column differ by Tukey's test (5\%).

\section{Gloss}

Gloss means for acrylic resins submitted to microwave disinfection are shown in Table 3. At baseline (no disinfection) and after disinfection cycle at 7 days, QC-20, Onda Cryl and Vipi Cril Plus showed highest values followed by Classico and Vipi Wave while Vipi Characterized was intermediate. After disinfection cycle at 14 days, QC-20 showed highest value followed by Classico and Vipi Wave while Onda Cryl, Vipi Cril Plus and Vipi Charcterized were intermediaries. After disinfection cycle at 21 days, QC-20 showed highest value followed by Classico, Vipi Wave and Vipi Characterized while Onda Cryl and Vipi Cril Plus were intermediaries. After disinfection cycle at 30 days, QC-20 showed highest value followed by Vipi Wave while Onda Cryl, Classico, Vipi Cril Plus and Vipi Characterized were intermediaries.

Comparing cycles in relation to each resin, gloss values for all cycles were similar only for Classico. For QC-20, baseline and cyclesat 7 and 14 days showed highest values followed by cyclesat 21 and 30 days. For Onda Cryl, baseline showed highest value followed by cycleat 7 days, and cycles at 21 and 30 days showed lowest values while cycle at 14 days was intermediate. For Vipi Cril Plus and Vipi Wave, baseline showed highest values followed by cycleat 14 days, and cycleat 30 days showed lowest value while cycles at 7 and 21 days were intermediaries. For Vipi Characterized, baseline showed highest value followed by cycle at 7 days, and cycles at 21 and 30 days presented lowest values while cycle at 14 days was intermediate.

\section{Discussion}

In the current study, surface roughness, Knoop hardness and gloss of denture base acrylic resins were evaluated in baseline and after microwave disinfection by using cycles at 7, 14, 21 and 30 days. Considering the different results obtained in the study, the hypothesis that roughness, hardness and gloss of acrylic resins would be similarly affected by different microwave disinfection cycles was rejected.

It has been alleged that polished acrylic resins show roughness value between 0.03 to $0.75 \mu \mathrm{m}$. Conventionally polished in lathe, the samples of the current study showed roughness values that range from 0.295 (Vipi Cril Plus) to $0.735 \mu \mathrm{m}$ (Classico) for baseline treatment. In this way, the polished surfaces present highest roughness values than the threshold of $0.2 \mu \mathrm{m}$ necessary for adhesion and retention of biofilm [22]. In agreement, the aforementioned study showed that the roughness caused by tooth brushing ranged from 3.4 to $7.6 \mu \mathrm{m}$, and it was also demonstrated that this denture base surface condition could be a tendency for biofilm accumulation [23].

In general, Table 1 shows that at baseline and microwave disinfection cycles showed different roughness levels when the acrylic resins were compared. Since the chemical composition of the acrylic resins is similar, it is possible that the results had occurred due to association between polymerization type (each one with their characteristics of heating and processing time) and disinfection (similar cycles for the acrylic resins). Except for QC-20, Onda Cryl and Vipi Characterized resins, the results showed statistically significant difference for Classico, Vipi Cril Plus and Vipi Wave when the cycles were compared. For these materials, highest roughness occurred for cycle at 30 days, showing possible deleterious effects on the sample surface submitted to larger time of microwave disinfection.

In agreement, previous work has shown that the acrylic resin den- 
ture base surface roughness mechanically polished increased after microwave disinfection performed twice with at 7-day interval [21]. It is difficult to understand and explain because resins fabricated by the same manufacturer (microwaved Onda Crylx conventional Classico, and conventional Vipi Cril Plus x microwaved Vipi Wave x conventional Vipi Characterized) showed different results when submitted to the same disinfection cycles by microwave irradiation, and also when each resin was evaluated among different microwave cycles. Differently from the current results, the literaturs has shown that conventional and boiled polymerization methods promoted similar roughnesses on the QC-20 and Classico acrylic resins; however, the roughness levels for both resins were higher [24].

A supposition for this fact could be based in the different amount of microporosity on the surface of the different acrylic resins, changing the roughness values. However, the literature has shown that the number of micropores isdifferent for different autopolymerized denture reline materials; however, the number of pores in acrylic resin for denture bases remained unaffected after microwave disinfections [25].

In addition, conventional polishing used in most prosthetic laboratories has been the most effective technique for polishing the denture base [26], which could improve the resistance of the material against the microwave effects on the surface roughness levels.

Hardness is an important mechanical property for denture base acrylic resins, and it is considered as the resistance of the material surface to penetration of a diamond tip [27]. Conventionally polished in lathe, the samples of the current study showed hardness values (KHN) that range from 22.50 (Vipi Wave) to 25.24 (Onda Cryl) for baseline period.

Table 2 shows that baseline and cycles of microwave disinfection showed different hardness levels for acrylic resins. In general, highest hardness occurred at baseline for these materials, and diminished values were seen when submitted to different cycles of microwave disinfection. Except for Vipi Cril Plus, the findings showed differences for QC-20, Onda Cryl, Classico, Vipi Wave, and Vipi Characterized when base line and disinfection cycles were compared in each acrylic resin type. Despite of chemical composition of these materials be considered similar, the hardness of resins fabricated by different manufacturers may have been influenced by the different amount of cross linkage agent in each composition. This supposition appears to be consistent when the results showed different hardness values between resins fabricated by the same manufacturer, but polymerized by different ways.

After disinfection procedure, it was observed a decrease of the hardness values for most acrylic resins. This result is in agreement with the previous study that reported hardness decrease for acrylic resins after microwave irradiation, but no effect was observed on the impact and flexural strength [16]. Moreover, conventional and boiled polymerization cycles promoted similar roughness and surface hardness for QC-20 and Classico resins [24]; however, the hardness levels for both resins were lesser than those seen in the current study. Based on these results, it is possible to presume smaller rigidity of the resins with the increase of the microwave cycles, which seems to confirm the decrease of the Knoop hard- ness after repeated microwave disinfections [17], after thermal cycling and disinfection procedures [28], and under effect of different polymerization cycles and water storage [29]. Conversely, the Vickers hardness of autopolymerized resins was not detrimentally affected by microwave disinfection with times from 1 to $5 \mathrm{~min}$ performed twice [30], and hardness of three denture base resins were not altered after simulated microwave disinfections at $650 \mathrm{~W}$ for $5 \mathrm{~min}$ [31], probable due to the shorter time of disinfection used in these aforementioned studies.

Gloss is considered an important organoleptic property related to prosthesis aesthetics, and may be influenced by the microwave disinfection because this procedure increases the roughness of acrylic resins and different reline materials [12]. Moreover, the color stability of acrylic resins was significantly affected by microwave disinfection method; however, the obtained gloss values are within acceptable clinical parameters [32]. If an analogy is possible, the increase of the roughness and decrease of the color stability of acrylic resins probably would change the surface gloss of the denture base.

Table 3 shows that baseline and cycles of microwave disinfection showed different gloss levels for acrylic resins. In general, highest gloss values occurred at baseline for these materials, and diminished values were seen when submitted to different cycles of microwave disinfection. Except for Classico, the findings showed differences for QC-20, Onda Cryl, Vipi Wave, and Vipi Characterized when base line and disinfection cycles were compared in each materialtype. Except for QC-20 in the cycles at 7 and 14 days, diminished gloss values were seen for other resins when submitted to different cycles of microwave disinfection, showing the possible harmful effect of this procedure on the gloss.

In these conditions, it is possible to assume that gloss loss could be related to smoothness change of the resin surface that occurred in the microwave treatment. This assumption is based on the fact that light incidence on the smooth surface occurs in conditions different from that in rough surface, since the gloss values are dependent of the angle of incidence, resulting in different reflection and absorption of the incident light. In addition, the number of disinfection cycles would also have a significant influence on the acrylic resin surface gloss, and would also be dependent of the polymerization method. However, to confirm or not this supposition would be necessary further studies analyzing the relationship among these variables.

On the other hand, chemical products for denture cleaning show high antimicrobial action, but they are incompatible with the metal components of the prosthesis whereas isopropyl and mouthwash products are antimicrobial but harmful for acrylic resins. However, special cleaning tablets for dental prostheses provided a good combination of microbial efficacy and compatibility reasonable with the polimeric material [33]. Moreover, all substances used by the patients promote surface abrasion of the denture base which reduced the reflection, and hard toothbrush associated with toothpaste showed also greatest abrasive effect, while soft toothbrush caused least damage [34].

\section{Conclusions}

Based on the results statistically analyzed and discussed, the fol- 
lowing conclusions may be drawn: Roughness, Knoop hardness and gloss values of different acrylic resins for denture base were differentelly influenced after subjected to disinfection cycles at 7 , 14, 21 and 30 days.

\section{References}

[1]. Coulthwaite L, Verran J. Potential pathogenic aspects of denture plaque. $\mathrm{Br} \mathrm{J}$ Biomed Sci. 2007 Feb; 64(4):180-189. PubMed PMID: 18236742.

[2]. Budtz-Jorgensen E. Etiology, pathogenesis, therapy, and prophylaxis of oral yeast infections. Acta Odontol Scand. 1990 Feb;48(1):61-69. PubMed PMID: 2181812.

[3]. Lombardi T, Budtz-Jorgensen E. Treatment of denture induced stomatitis: a review. Eur J Prosthodont Restor Dent .1993 Sep;2(1):17-22. PubMed PMID:8180613.

[4]. Rossato MB, Unfer B, May LG, Braun KO. Analysis of the effectiveness of different hygiene procedures used in dental prostheses. Oral Health Prev Dent. 2011 Jan;9(3):221-227. PubMed PMID: 22068177.

[5]. Skupien JA, Valentini F, Boscato N, Pereira-Cenci T. Prevention and treatment of Candida colonization on denture liners: a systematic review. J Prosthet Dent. 2013 Nov; 110(5):356-362. PubMed PMID: 23998622.

[6]. Martínez A, Catalán A, Rojas N, Torres V, Acuña M. In vitro effectiveness of a terpenic denture cleanser on old biofilm surfaces. J Prosthodont. 2016 Sep 6. Doi: 10.1111/jopr.12531. PubMed PMID: 27598657.

[7]. Panariello BH, Izumida FE, Moffa EB, Pavarina AC, Jorge JH, Giampaolo ET. Effect of mechanical toothbrushing combined with different denture cleansers in reducing the viability of a multispecies biofilm on acrylic resins. Am J Dent. 2016 Jun;29(3):154-160. PubMed PMID: 27505992.

[8]. Silva MM, Vergani CE, Giampaolo ET, Neppelenbroek KH, Spolidorio DM, Machado AL. Effectiveness of microwave irradiation on the disinfection of complete dentures. Int J Prosthodont. 2006 May;19(3):288-293. PubMed PMID: 16752628.

[9]. Rao DC, Kalavathy N, Mohammad HS, Hariprasad A, Kumar CR. Evaluation of the surface roughness of three heat-cured acrylic denture base resins with different conventional lathe polishing techniques: A comparative study. J Indian Prosthodont Soc. 2015 Oct;15(4):374-380. PubMed PMID: 26929542.

[10]. Bollen CML, Lambrechts P, Quirynem M. Comparison of surface roughness of oral hard material to the threshold surface roughness for bacterial plaque retention: A review of the literature. Dent Mater. 1997 Jul;13(4):258-269. PubMed PMID: 11696906.

[11]. Berger JC, Driscoll CF, Romberg E, Luo Q, Thompson G. Surface roughness of denture base acrylic resins after processing and after polishing. J Prosthodont. 2006 May;15(3):180-186. PubMed PMID: 16681500.

[12]. Machado AL, Giampaolo ET, Pavarina AC, Jorge JH, Vergani CE. Surface roughness of denture base and reline materials after disinfection by immersion in chlorhexidine or microwave irradiation. Gerodontology. 2012 Jun;29(2):e375- e382. PubMed PMID: 21615783.

[13]. Polychronakis NC, Polyzois GL, Lagouvardos PE, Papadopoulos TD. Effects of cleansing methods on 3-D surface roughness, gloss and color of a polyamide denture base material. Acta Odontol Scand 2015 Jul;73(5):353-363. PubMed PMID: 25367196.

[14]. Webb BC, Thomas CJ, Whittle T. A 2-year study of Candida-associated denture stomatitis treatment in aged care subjects. Gerodontology. 2005 Sep;22(3):168-76. PubMed PMID: 16163908

[15]. Neppelenbroek KH, Pavarina AC, Palomari Spolidorio DM, Sgavioli Massucato EM, Spolidorio LC, Vergani CE. Effectiveness of microwave disinfection of complete dentures on the treatment of Candida - releated denture stomatitis. J Oral Rehabil. 2008 Nov;35(11):836-846. PubMed PMID: 18466276

[16]. Consani RLX, Vieira EB, Mesquita MF, Mendes WB, Arioli-Filho JN. Effect of microwave disinfection on physical and mechanical properties of acrylic resins. Braz Dent J. 2008;19(4):348-353. PubMed PMID: 19180326.

[17]. Consani RLX, Azevedo DD, Mesquita MF, Mendes WB, Saquy PC. Effect of repeated disinfections by microwave energy on the physical and mechanical properties of denture base acrylic resins. Braz Dent J. 2009;20(2):132137. PubMed PMID: 19738946.

[18]. Izumida FE, Ribeiro RC, Giampaolo ET, Machado AL, Pavarina AC, Vergani CE. Effect of microwave disinfection on the surface roughness of three denture base resins after tooth brushing. Gerodontology. 2011 Dec;28(4):277282. PubMed PMID: 21342242.

19]. Pavan S, Arioli Filho JN, Dos Santos PH, Mollo F. Effect of microwave treatments on dimensional accuracy of maxillary acrylic resin denture base. Braz Dent J. 2005;16(2):119-123. PubMed PMID: 16475605.

[20]. Consani RLX, Mesquita MF, Nobilo MAA, Henriques GEP. Influence of simulated microwave disinfection on complete denture base adaptation using different flask closure methods. J Prosthet Dent 2007 Mar;97(3):173178. PubMed PMID: 17394916.

[21]. Sartori EA, Schmidt CB, Walber LF, Shinkai RS. Effect of microwave disinfection on denture base adaptation and resin surface roughness. Braz Dent J.2006;17(3):195-200. PubMed PMID: 17262124.

[22]. Zissis AJ, Polyzois GL, Yannikakis SA, Harrison A. Roughness of denture materials: A comparative study. Int J Prosthodont.2000 Mar;13(2):136-140. PubMed PMID:11203622.

[23]. Verran J, Jackson S, Coulthwaite L, Scallan A, Loewy Z, Whitehead K.The effect of dentifrice abrasion on denture topography and the subsequent retention of microorganisms on abraded surfaces. J Prosthet Dent. 2014 Dec;112(6):1513-1522. PubMed PMID: 24998324

[24]. Consani RL, Folli BL, Nogueira MC, Correr AB, Mesquita MF. Effect of polymerization cycles on gloss, roughness, hardness and impact strength of acrylic resins. Braz Dent J. 2016 Mar;27(2):176-180. PubMed PMID: 27058380.

[25]. Novais PMR, Giampaolo ET, Vergani CE, Machado AL, Pavarina AC, Jorge $\mathrm{JH}$. The occurrence of porosity in reline acrylic resins: Effect of microwave disinfection. Gerodontology. 2009 Mar;26(1): 65-71. PubMed PMID: 18707626.

[26]. Gungor H, Gundogdu M, Yesil Duymus Z. Investigation of the effect of different polishing techniques on the surface roughness of denture base and repair materials. J Prosthet Dent. 2014 Nov;112(5):1271-1277. PubMed PMID: 24853341

[27]. Anusavice KJ. Phillip's Science of Dental Materials. 11th ed. Philadelphia: Elsevier; 2013.

[28]. Goiato MC, Dos Santos DM, Baptista GT, Moreno A, Andreotti AM, Dekon SF. Effect of thermal cycling and disinfection on microhardness of acrylic resin denture base. J Med Eng Technol. 2013 Apr;37(3):203-207. PubMed PMID: 23631521.

[29]. Xediek Consani RL, Chorwat V, Ferraz Mesquita M, Fernandes Santos MB, Bortolazzo Correr A, Consani S. Effect of simulated microwavedisinfection on the linear dimensional change, hardness and impact strength of acrylic resins processed by different polymerization cycles. Minerva Stomatol. 2014 May;63(5):145-154. PubMed PMID: 25047260.

[30]. Ribeiro DG, Pavarina AC, Machado AL, Giampaolo ET, Vergani CE. Flexural strenght and hardness of reline and denture base acrylic resins after diferente exposure times of microwave disinfection. Quintessence Int. 2008 Nov;39(10):833-840. PubMed PMID: 19093060.

[31]. Konchada J, Karthigeyan S, Ali SA, R V, Amirisetty R, Dani A. Effect of simulated microwave disinfection on the mechanical properties of three different types of denture base resins. J Clin Diagn Res. 2013 Dec;7(12):30513053. PubMed PMID: 24551725.

[32]. Goiato MC, Dos Santos DM, Baptista GT, Moreno A, Andreoti AM, Bannwart LC, et al. Effect of termal cycling and disinfection on colour stability of denture base acrylic resin. Gerodontology. 2013 Dec; 30(4): 276-282. PubMed PMID: 22519836.

[33]. Kiesow A, Sarembe S, Pizzey RL, Axe AS, Bradshaw DJ. Material compatibility and antimicrobial activity of consumer products commonly used to clean dentures. J Prosthet Dent. 2016 Feb;115(2):189-198. PubMed PMID:26545863.

[34]. Žilinskas J, Junevičius J, Česaitis K, Junevičiūte G. The effect of cleaning substances on the surface of denture base material. Med Sci Monit. 2013 Dec;19:1142-1145. PubMed PMID: 24326781. 